\title{
Risk factors of tubal infertility in a tertiary hospital in a low-resource setting: a case- control study
}

Thomas Obinchemti Egbe ${ }^{1,2^{*}}$ (D), Theophile Nana-Njamen ${ }^{1,2}$, Felix Elong ${ }^{2}$, Robert Tchounzou², Andre Gaetan Simo², Gaelle Padjip Nzeuga ${ }^{3}$, Cedric Njamen Nana' ${ }^{1}$ Emmanuella Manka'a ${ }^{4}$, Charlotte Tchente Nguefack ${ }^{1,5}$ and Gregory Edie Halle-Ekane ${ }^{1,2}$

\begin{abstract}
Background: Infertility is the inability to sustain a pregnancy in a woman with regular (2-3 times per week) unprotected sexual intercourse for a period of 1 year. This is a major public health problem that remains underrecognised in Cameroon and most countries in sub-Saharan Africa. This study aimed at identifying the risk factors associated with tubal infertility in a tertiary hospital in Douala, Cameroon.

Methods: We conducted a case-control study at the Obstetrics, Gynaecology and Radiology Departments of the Douala Referral Hospital from October 1, 2016, to July 30, 2017. We recruited 77 women with tubal infertility diagnosed using hysterosalpingography and 154 unmatched pregnant women served as controls. Data on socio-demographic, reproductive and sexual health, and radiologic assessments were collected using a pretested questionnaire. The data were analysed using the Statistical Package for the Social Sciences (SPSS) software version 24.0. Logistic regression models were fitted to identify demographic, reproductive health factors, surgical, medical and toxicological factors associated with tubal infertility. The adjusted odds ratios (AOR) and their 95\% confidence interval were interpreted. Statistical significance set at $p<0.05$.

Results: Sixty-one per cent of respondents had secondary infertility. Following multivariate logistic regression analysis, respondents who were housewives (AOR 10.7; 95\% Cl: 1.68-8.41, $p=0.012$ ), self-employed (AOR 17.1; 95\% Cl: $2.52-$ $115.8, p=0.004$ ), with a history of Chlamydia trachomatis infection (AOR 17.1; 95\% Cl: 3.4-85.5, $p=0.001$ ), with Mycoplasma infection (AOR 5.1; 95\% Cl: 1.19-22.02, $p=0.03$ ), with ovarian cyst (AOR 20.5; 95\% Cl: 2.5-168.7, $p=0.005$ ), with uterine fibroid (AOR 62.4; 95\% Cl: 4.8-803.2, $p=0.002$ ), have undergone pelvic surgery (AOR 2.3; 95\% Cl: 1.0-5.5, $p=0.05$ ), have undergone other surgeries (AOR 49.8; 95\% Cl: 6.2-400, $p=0.000$ ), diabetic patients (AOR 10.5; $95 \% \mathrm{Cl}$ $1.0-113.4, p=0.05$ ) and those with chronic pelvic pain (AOR 7.3; 95\% Cl: 3.2-17.1, $p=0.000$ ) were significantly associated with tubal infertility while the young aged from 15 to 25 (AOR $0.07 ; 95 \% \mathrm{Cl}: 0.01-0.67,0.021$ ), those in monogamous marriages (AOR 0.05; 95\% Cl: 0.003-1.02, $p=0.05$ ), as well as those with a history of barrier contraceptive methods (condom) (AOR 0.17; 95\% Cl: 0.03-1.1, $p=0.06$ ) were less likely to have tubal infertility.

(Continued on next page)
\end{abstract}

\footnotetext{
* Correspondence: toegbe@gmail.com; obinchemti@yahoo.com

'Department of Obstetrics and Gynecology, Douala Referral Hospital, Douala,

Cameroon

${ }^{2}$ Faculty of Health Sciences, University of Buea, Buea, Cameroon

Full list of author information is available at the end of the article
}

(c) The Author(s). 2020 Open Access This article is licensed under a Creative Commons Attribution 4.0 International License, which permits use, sharing, adaptation, distribution and reproduction in any medium or format, as long as you give appropriate credit to the original author(s) and the source, provide a link to the Creative Commons licence, and indicate if changes were made. The images or other third party material in this article are included in the article's Creative Commons licence, unless indicated otherwise in a credit line to the material. If material is not included in the article's Creative Commons licence and your intended use is not permitted by statutory regulation or exceeds the permitted use, you will need to obtain permission directly from the copyright holder. To view a copy of this licence, visit http://creativecommons.org/licenses/by/4.0/ The Creative Commons Public Domain Dedication waiver (http://creativecommons.org/publicdomain/zero/1.0/) applies to the data made available in this article, unless otherwise stated in a credit line to the data. 
(Continued from previous page)

Conclusion: The following factors were independently associated with tubal infertility: being a housewife, selfemployed, history of Chlamydia trachomatis, Mycoplasma infection, and uterine fibroid. Furthermore, a history of pelvic surgery and other surgeries, diabetes mellitus, and chronic pelvic pain were also associated with tubal infertility. Young age, persons in monogamous marriages and users of barrier methods of contraception (condom) were less likely to have tubal infertility. Identification of these factors will be a target of intervention to avoid tubal infertility.

Keywords: Tubal infertility, Associated risk factors, Pelvic inflammatory disease, Sexually transmitted infections

\section{Background}

Infertility is the inability to sustain a pregnancy in a woman with regular (2-3 times per week) unprotected sexual intercourse for a period of 1 year [1]. Though it is a major public health problem, infertility in subSaharan Africa remains largely under-recognised [2, 3]. An infertility belt has actually been described in Africa that cuts across West and Central Africa, including Cameroon [4]. Though the prevalence of infertility has been widely reported in medical literature, it is difficult to synthesize infertility prevalence data because of the incomparable definitions used [5]. However, in Africa, and Cameroon, in particular, this prevalence has been underestimated because infertile patients do not readily seek medical attention for various reasons including lack of awareness or knowledge, lack of resources as well as cultural and religious reasons [6-8]. It has been reported, previously, in Yaoundé, Cameroon that the female factor accounts for $30 \%$ of infertility; with infectious causes mainly Chlamydia, accounting for $48.9 \%$ [9]. There are few studies in Cameroon that report the risk factors associated with infertility. This study aimed at identifying the risk factors associated with tubal infertility at the Douala Referral Hospital, Cameroon.

\section{Patients and methods}

\section{Study design and site}

We conducted a case-control study from October 1, 2016 to July 30, 2017 at the Obstetrics and Gynaecology and Radiology Departments of the Douala Referral Hospital (DRH)). The DRH is a tertiary health facility that provides scientific treatment, research and teaching, and serves as a referral hospital for Douala and the Central African sub-region. The Department of Obstetrics and Gynaecology has eight obstetricians/ gynaecologists while the Department of Radiology has three radiologists. Patients who were consulted by the gynaecologist were later referred to the radiologists for hysterosalpingography (HSG) after screening and treating for vaginal infections. We enrolled consenting women suffering from infertility and whose HSG results showed bilateral tubal occlusion. We excluded women with other causes of infertility like diminished ovarian reserve, male factor, uterine factor, or ovulatory factor. The sperm count of the partner was normal. The control group consisted of consenting women who became pregnant naturally and came for antenatal care visits during the study period.

\section{Study procedure}

- After obtaining ethical approval from the research board of the DRH, respondents signed a written informed consent form to take part in the study. Women with a diagnosis of infertility and pregnant controls were administered pretested questionnaires consisting of:

- Sociodemographic information: age, marital status, level of education and occupation

- Reproductive health characteristics: age at first intercourse, contraception use and type, parity, number of lifetime sex partners, type of dysmenorrhea, histories of ectopic pregnancies, uterine fibroid, ovarian cysts, spontaneous and induced abortions, use of traditional vaginal herbs, type of infertility, duration of infertility, infection screening (Chlamydia trachomatis, Mycoplasma), history of PID and lesions found on hysterosalpingography (unilateral or bilateral tubal obstruction). For this study, we considered only bilateral tubal occlusion for tubal infertility

- Past medical, surgical and toxicological history: history of pelvic and other surgeries, diabetes mellitus, tobacco smoking

The HSG was performed on out-patient basis during the proliferative phase that is during the 7 th-12th day of menstrual cycle (the 1st day being the menstrual bleeding and women with a regular cycle) using the standard technique [10-12]. All the procedures were performed at the DRH and reviewed for endometrial and tubal pathologies by three experienced radiologists to avoid inter-observer bias.

There were, 77 respondents with tubal factor infertility (cases) and 154 controls (women who came for antenatal care visits) (Fig. 1). Reporting was according to the Strokes guidelines. 


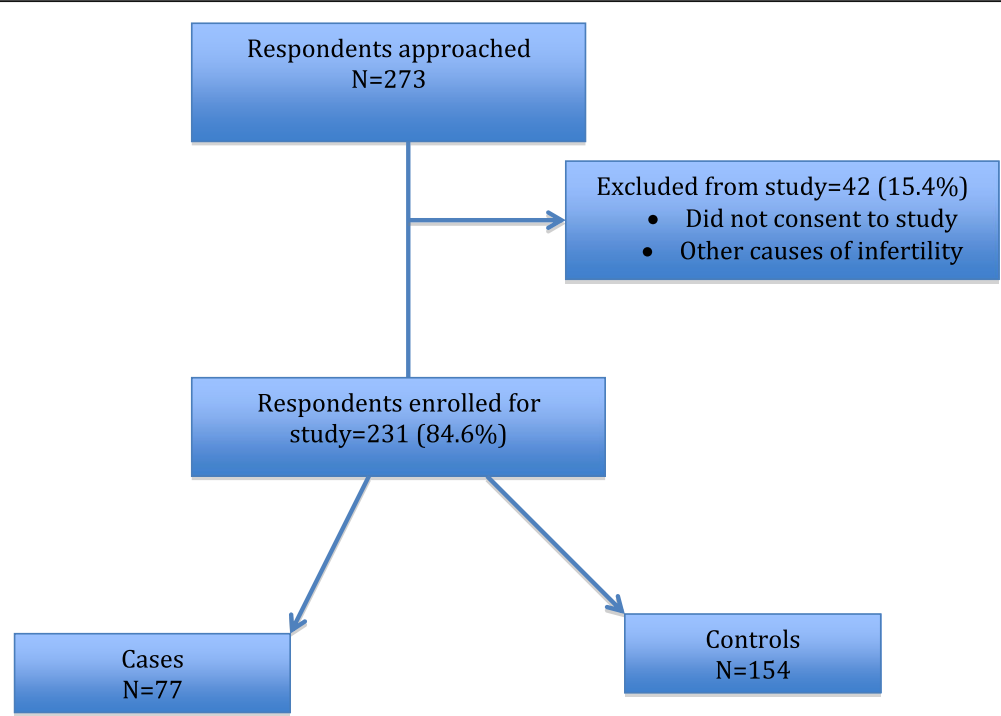

Fig. 1 Flow diagram of study population

\section{Data management and analysis}

Data were coded and double entered into Microsoft excel 2013 by two separate researchers to avoid errors. The data were analysed using the Statistical Package for the Social Sciences (SPSS) software version 24.0. Logistic regression models were fitted to identify demographic, reproductive health factors, surgical, medical and toxicological factors associated with tubal infertility. The adjusted odds ratios (AOR) and their 95\% confidence interval were interpreted. The threshold for type 1 error was set at $5 \%$.

\section{Results}

Figure 1 shows that we approached 273 respondents at the Obstetrics and Gynaecology Department of the DRH, among which 231 (84.6\%) were enrolled for study and $42(15.4 \%)$ were excluded from study because they did not consent to study or had other causes of infertility. Among this group, 77 had tubal factor infertility (cases) and 154 women with spontaneous pregnancies who came for antenatal care visits served as controls. Furthermore, $61 \%(47 / 77)$ of cases had secondary infertility. Respondent's age ranged from 15 to 43 years with a mean age of 30.6 (SD 5.97) years.

Table 1 shows that there is no significant difference between the two groups with regard to those under the age of 35, level of education, region of origin, and most professions aside from self-employed $(p<0.001)$.

\section{Risk factors of tubal infertility (multivariate analysis)}

Table 2 shows the socio-demographic factors associated with tubal infertility.

Respondents who were housewives (AOR 10.7; 95\% CI: 1.68-8.41, $p=0.012$ ) and those who were self-employed
(AOR 17.1; 95\% CI: 2.52-115.8, $p=0.004$ ) were significantly associated with tubal infertility while young age 1525 years (AOR 0.07; 95\% CI: 0.01-0.67, 0.021) and those who married monogamously (AOR 0.05; 95\% CI: $0.003-$ $1.02, p=0.05$ ) were less likely to have tubal infertility.

Table 3 shows the reproductive health characteristics that were independently associated with tubal infertility.

Respondents with a history of Chlamydia trachomatis infection (AOR 17.1; 95\% CI: 3.4-85.5, $p=0.001$ ), Mycoplasma infection (AOR 5.1; 95\% CI: 1.19-22.02, $p=$ 0.03 ), ovarian cyst (AOR 20.5; 95\% CI: 2.5-168.7, $p=$ 0.005 ) and those with uterine fibroids (AOR 62.4; $95 \%$ CI: 4.8-803.2, $p=0.002$ ) were significantly associated with tubal infertility. However, respondents with a history of use of barrier contraceptive methods (condom) (AOR 0.17; 95\% CI: $0.03-1.1, p=0.06$ ) were less likely to have tubal infertility during the study period.

Table 4 shows the medical and surgical factors independently associated with tubal infertility.

Participants who had undergone other surgeries (AOR 49.8; 95\% CI: 6.2-400, $p=0.000$ ), pelvic surgery (AOR 2.3; 95\% CI: $1.0-5.5, p=0.05$ ), diabetic patients (AOR 10.5 ; 95\% CI 1.0-113.4, $p=0.05$ ) and those with chronic pelvic pain (AOR 7.3; 95\% CI: 3.2-17.1, $p=0.000$ ) were significantly associated with tubal infertility.

\section{Discussion}

We conducted a case-control study that aimed at identifying the risk factors associated with tubal factor infertility at the Douala Referral Hospital, Cameroon.

The risk factors of tubal infertility were: being a housewife, self-employed, history of Chlamydia trachomatis, Mycoplasma infection, and uterine fibroids. Furthermore, the history of pelvic surgery and other surgeries, 
Table 1 Socio-demographic characteristics of study population

\begin{tabular}{|c|c|c|c|c|c|c|c|}
\hline \multirow[t]{2}{*}{ Variables } & \multicolumn{2}{|c|}{ Frequency cases $=77$} & \multicolumn{2}{|c|}{ Frequency controls $=154$} & \multirow[t]{2}{*}{ Odd ratios } & \multirow[t]{2}{*}{$95 \% \mathrm{Cl}$} & \multirow[t]{2}{*}{$P$-value } \\
\hline & $N$ & $\%$ & $N$ & $\%$ & & & \\
\hline \multicolumn{8}{|l|}{ Age (years) } \\
\hline $15-25$ & 1.0 & 1.3 & 37 & 24 & 0.07 & $0.09-0.51$ & 0.09 \\
\hline $25-35$ & 55 & 71.4 & 96 & 62.3 & 0.67 & $0.38-1.19$ & 0.171 \\
\hline $35-45$ & 21 & 27.3 & 21 & 13.6 & 3.64 & $1.92-6.88$ & $<0.001$ \\
\hline \multicolumn{8}{|l|}{ Marital status } \\
\hline Single & 24 & 31.2 & 62 & 40.3 & 0.67 & $0.38-1.20$ & 0.18 \\
\hline Cohabitation & 14 & 18.2 & 1 & 0.6 & 34 & $4.38-264.07$ & 0.001 \\
\hline Monogamy & 37 & 48.1 & 91 & 59.1 & 0.66 & $0.38-1.14$ & 0.136 \\
\hline Polygamy & 2 & 2.6 & 1 & 0.6 & 4.08 & $0.36-45.71$ & 0.254 \\
\hline \multicolumn{8}{|l|}{ Level of education } \\
\hline Primary & 28 & 36.4 & 46 & 29.9 & 0.86 & $0.44-1.67$ & 0.66 \\
\hline Secondary & 41 & 53.2 & 92 & 59.7 & 0.75 & $0.43-1.30$ & 0.31 \\
\hline Tertiary & 8 & 10.4 & 16 & 10.4 & 2.14 & $0.07-12.7$ & 0.97 \\
\hline \multicolumn{8}{|l|}{ Profession } \\
\hline Civil servant & 29 & 37.7 & 54 & 35.1 & 1.12 & $0.63-1.97$ & 0.698 \\
\hline Private sector & 14 & 18.2 & 22 & 14.3 & 1.33 & $0.64-2.78$ & 0.443 \\
\hline Student/pupil & 15 & 19.5 & 13 & 8.4 & 2.62 & $1.18-5.84$ & 0.018 \\
\hline Self-employed & 3 & 3.9 & 40 & 1.9 & 0.12 & $0.034-0.39$ & $<0.001$ \\
\hline Housewife & 16 & 20.8 & 25 & 16.2 & 1.42 & $0.70-2.87$ & 0.327 \\
\hline \multicolumn{8}{|l|}{ Region of origin } \\
\hline Adamawa & 2 & 2.6 & 4 & 2.6 & 1.34 & $0.22-8.21$ & 0.75 \\
\hline Center & 10 & 12.9 & 17 & 11.0 & 1.20 & $0.52-2.77$ & 0.66 \\
\hline East & 15 & 19.5 & 21 & 13.6 & 1.62 & $0.78-3.38$ & 1.20 \\
\hline West & 29 & 37.6 & 64 & 41.5 & 0.83 & $0.47-1.45$ & 0.51 \\
\hline Northwest & 1 & 1.3 & 3 & 1.9 & 0.66 & $0.07-6.47$ & 0.72 \\
\hline Far North & 1 & 1.3 & 4 & 2.6 & 0.49 & $0.05-4.49$ & 0.53 \\
\hline North & 2 & 2.6 & 6 & 3.9 & 0.66 & $0.13-3.34$ & 0.61 \\
\hline South & 7 & 9.1 & 13 & 8.4 & 1.09 & $0.41-2.84$ & 0.87 \\
\hline Southwest & 4 & 5.2 & 10 & 6.5 & 0.79 & $0.24-2.78$ & 0.70 \\
\hline Littoral & 6 & 7.8 & 12 & 7.8 & 1.00 & $0.36-2.78$ & 1.00 \\
\hline
\end{tabular}

$\mathrm{Cl}$ Confidence interval, $N$ Number, \% Percentage

diabetes mellitus, and chronic pelvic pain were also associated with tubal infertility. Young age, those in monogamous marriages and users of barrier methods of contraception (condom) were less likely to have tubal infertility.

\section{Sociodemographic variables associated with tubal infertility}

Sixty-one per cent of patients in the study had secondary infertility with $35.1 \%$ (27/77) being parous. Besides, other studies have reported that parity, however, may be an inappropriate substitute for infertility because it cannot account for pregnancy intention [13].
In this study, housewives and the self-employed respondents were prone to have tubal infertility. The reason for this may be associated with poor sexual habits of their partners. There is still free sex life among men and especially those engaged in liberal businesses in Cameroon. This is compounded with the low use of barrier family planning methods especially the condom. Some men believe that condom use reduces sexual pleasure and men who have this belief are less likely to use the condom [14]. The non-use of condoms is associated with increased risk of genital tract infection in the partners especially PID that may later lead to tubal obstruction and infertility. It has been reported that infertility in most low-income countries is from genital tract 
Table 2 Demographic factors associated with tubal infertility (multivariate analysis)

\begin{tabular}{|c|c|c|c|c|c|c|}
\hline \multirow[t]{2}{*}{ Variable } & \multirow[t]{2}{*}{ Levels } & \multirow{2}{*}{$\begin{array}{l}\text { Cases } \\
n(\%)\end{array}$} & \multicolumn{4}{|l|}{ Control } \\
\hline & & & $n(\%)$ & $\mathrm{AOR}$ & $95 \% \mathrm{Cl}$ & Sig. \\
\hline \multirow[t]{3}{*}{ Age } & $15-25$ & $1(0.4)$ & $37(16.1)$ & 0.072 & $0.01-0.67$ & 0.021 \\
\hline & $26-35$ & $56(24.3)$ & $94(40.9)$ & 0.592 & $0.27-1.31$ & 0.195 \\
\hline & $35-45$ & $22(9.6)$ & $20(8.7)$ & 1 & & \\
\hline \multirow[t]{4}{*}{ Marital status } & Single & $25(10.9)$ & $61(26.5)$ & 0.067 & $0.003-1.38$ & 0.080 \\
\hline & Cohabiting & $14(6.1)$ & $1(0.4)$ & 1.995 & $0.06-66.79$ & 0.700 \\
\hline & Monogamy & $38(6.1)$ & $88(38.3)$ & 0.051 & $0.003-1.02$ & 0.052 \\
\hline & Polygamy & $2(0.9)$ & $1(0.4)$ & 1 & & \\
\hline \multirow[t]{3}{*}{ Level of education } & Higher & $28(12.4)$ & $31(13.8)$ & 1.734 & $0.82-0.67$ & 0.151 \\
\hline & Primary & $15(6.7)$ & $33(14.7)$ & 0.688 & $0.28-1.70$ & 0.419 \\
\hline & Secondary & $36(16.0)$ & $82(36.4)$ & 1 & & \\
\hline \multirow[t]{5}{*}{ Profession } & Housewife & $17(7.4)$ & $23(10.0)$ & 10.722 & $1.68-8.41$ & 0.012 \\
\hline & Private sector & $14(6.1)$ & $21(9.2)$ & 6.191 & $0.93-41.10$ & 0.059 \\
\hline & Civil servant & $30(13.1)$ & $53(23.1)$ & 5.451 & $0.92-32.35$ & 0.062 \\
\hline & Self-employed & $15(6.6)$ & $13(5.7)$ & 17.077 & $2.52-115.78$ & 0.004 \\
\hline & Students & $3(1.3)$ & $40(17.5)$ & 1 & & \\
\hline
\end{tabular}

The procedure models cases as the response, treating control as the reference category

$A O R$ Adjusted odd ratio, $\mathrm{Cl}$ Confidence interval

Table 3 Reproductive health factors associated with tubal infertility (multivariate analysis)

\begin{tabular}{|c|c|c|c|c|c|c|c|}
\hline \multirow[t]{2}{*}{ Variable } & \multirow[t]{2}{*}{ Levels } & \multirow{2}{*}{$\begin{array}{l}\text { Cases } \\
\text { n (\%) }\end{array}$} & \multirow{2}{*}{$\begin{array}{l}\text { Control } \\
\text { n (\%) }\end{array}$} & \multirow[t]{2}{*}{$\mathrm{AOR}$} & \multirow[t]{2}{*}{ Lower } & \multirow[t]{2}{*}{ Upper } & \multirow[t]{2}{*}{ Sign. } \\
\hline & & & & & & & \\
\hline \multirow[t]{2}{*}{ Age at first intercourse } & $15-20$ & $74(32.2)$ & $117(50.9)$ & 0.56 & 0.0 & 4.19 & 0.572 \\
\hline & $21-35$ & $5(2.2)$ & $34(14.8)$ & 1 & & & \\
\hline \multirow[t]{2}{*}{ Type of Dysmenorrhoea } & Secondary & $74(32.2)$ & $129(56.1)$ & 1.40 & 0.09 & 20.65 & 0.808 \\
\hline & Primary & $5(2.2)$ & $22(9)$. & 1 & & & \\
\hline \multirow[t]{2}{*}{ Given birth before } & Yes & $27(12.1)$ & $78(34.8)$ & 0.47 & 0.12 & 1.85 & 0.281 \\
\hline & No & $46(20.5)$ & $73(32.6)$ & 1 & & & \\
\hline \multirow[t]{2}{*}{ Use o condom } & Yes & $28(12.2)$ & $104(45.4)$ & 0.17 & 0.03 & 1.08 & 0.061 \\
\hline & No & $50(21.8)$ & $47(20.5)$ & 1 & & & \\
\hline \multirow[t]{2}{*}{ Number of sexual partners } & $>$ one & $21(9.1)$ & $16(7.0)$ & 3.42 & 0.62 & 18.81 & 0.158 \\
\hline & One partner & $58(25.2)$ & $135(58.7)$ & 1 & & & \\
\hline \multirow[t]{2}{*}{ Ovarian Cyst } & Yes & $13(5.7)$ & $6(2.6)$ & 20.45 & 2.48 & 168.67 & 0.005 \\
\hline & No & $66(28.7)$ & $145(3.0)$ & 1 & & & \\
\hline \multirow[t]{2}{*}{ Induced abortion } & Yes & $28(12.2)$ & $39(17.0)$ & 2.75 & 0.64 & 11.81 & 0.173 \\
\hline & No & $51(22.2)$ & $112(48.7)$ & 1 & & & \\
\hline \multirow[t]{2}{*}{ Chlamydia } & Yes & $38(16.5)$ & $12(5.2)$ & 17.05 & 3.40 & 85.53 & 0.001 \\
\hline & No & $41(17.8)$ & $139(60.4)$ & 1 & & & \\
\hline \multirow[t]{2}{*}{ Mycoplasma } & Yes & $43(18.7)$ & $27(11.7)$ & 5.13 & 1.19 & 22.02 & 0.028 \\
\hline & No & $36(15.7)$ & $124(53.9)$ & 1 & & & \\
\hline \multirow[t]{2}{*}{ Deep dyspareunia } & Yes & $29(12.6)$ & $7(3.0)$ & 3.73 & 0.38 & 36.40 & 0.258 \\
\hline & No & $50(21.7)$ & $144(62.6)$ & 1 & & & \\
\hline \multirow[t]{2}{*}{ Multiple uterine fibroids } & Yes & $20(8.7)$ & $3(1.3)$ & 62.35 & 4.84 & 803.18 & 0.002 \\
\hline & No & $59(25.7)$ & $148(64.3)$ & 1 & & & \\
\hline
\end{tabular}


Table 4 Surgical and medical factors associated with tubal infertility (multivariate analysis)

\begin{tabular}{|c|c|c|c|c|c|c|}
\hline & & & & AOR & $95 \% \mathrm{Cl}$ & Sig. \\
\hline \multirow[t]{2}{*}{ Other surgery } & Yes & $18(9.0)$ & $1(0.5)$ & 49.826 & $6.20-400.14$ & 0.000 \\
\hline & No & $52(2.0)$ & $129(64.5)$ & 1 & & \\
\hline \multirow[t]{2}{*}{ Pelvic surgery } & Yes & $19(8.3)$ & $19(8.3)$ & 2.318 & $0.98-5.47$ & 0.055 \\
\hline & No & $60(26.1)$ & $132(57.4)$ & 1 & & \\
\hline \multirow[t]{2}{*}{ Diabetes } & Yes & $3(1.3)$ & $1(0.4)$ & 10.494 & $0.97-113.38$ & 0.053 \\
\hline & No & $76(33.0)$ & $150(65.2)$ & 1 & & \\
\hline \multirow[t]{2}{*}{ Chronic pelvic pains } & Yes & $35(15.2)$ & $11(4.8)$ & 7.331 & $3.15-17.05$ & 0.000 \\
\hline & No & $44(19.1)$ & $140(60.9)$ & 1 & & \\
\hline
\end{tabular}

The procedure models cases as the response, treating control as the reference category

infection especially Chlamydia trachomatis leading to tubal infertility [15-17]. Women in Africa and Cameroon in particular seek care late, likely resulting in tubal disease from PID due to untreated Chlamydia infection [18]. Besides, a likely cause of infertility due to delayed presentation for treatment is age associated decline in ovarian reserve and egg quality due to aneuploidy $[19,20]$.

In this study, young age $15-25$ years was protective of tubal infertility. This is consistent with the literature which states that women over 35 years generally have twice the risk of unexplained infertility, ovulatory dysfunction and tubal factor infertility [21] The study in Cameroon corroborates the fact that most infertile women were in the 30 to 40 years age bracket [9].

From the different studies, fertility may be multifactorial. However, our study population are women exposed early to sexually transmitted infections, coupled with the fact that they seek proper care relatively late [18].

\section{Reproductive health variables associated with tubal infertility}

The protective association of condom use with infertility has consistently been reported in the literature [22-24]. Our study has shown that use of barrier contraception is protective of tubal infertility by preventing sexually transmitted infections and unwanted pregnancies. Voluntary termination of pregnancy is illegal in Cameroon. Therefore, most of these procedures are carried out in unorthodox conditions, sometimes by unqualified health or non-health professionals, resulting in increased rates of peritonitis, sepsis, and subsequent infertility [25-28].

The role of sexually transmitted infections in the genesis of fertility impairment is well documented and further corroborated in this study where Chlamydia trachomatis was 3.4-fold associated with tubal infertility [22-25]. In addition, an untreated STI is most often implicated in the development of PID and later fertility impairment $[24,25]$. Furthermore, it has been reported previously that chronic active Chlamydia infection is often associated with tubal infertility, may persist despite therapy, and can be detected by endometrial biopsy culture [26].

Healthcare providers are in an excellent place not only to assess women at risk for STI but also to help them in decreasing their risks. Young women in particular should be targeted for screening and intervention on "fertility protection". Of specific concern are the "silent" or atypical cases of PID that may present with vague symptoms but are not associated with pain; these infections are often only identified retrospectively during an infertility investigation [27, 28]. Unfortunately, there are no regular screening programmes for STI in Cameroon and in most cases only the antibody (serology) test for chlamydia is used.

There is also an increased prevalence of ectopic pregnancy likely due to undiagnosed or improperly treated STIs particularly $C$. trachomatis. The strength of the ectopic pregnancy variable speaks to the risks associated with undiagnosed and untreated sexually transmitted infections.

In this study the presence of uterine fibroids, especially when they are multiple, has been associated with tubal infertility. All our patients in Cameroon were of the black race. Therefore, they are prone to having uterine fibroids. It has been reported that uterine fibroids may be associated with tubal infertility (depending on the location of the fibroid) by local compression or occlusion of the tubal ostium or implantation failure. Submucosal fibroids had the strongest association with lower ongoing pregnancy rates, primarily through decreased implantation. Cumulative pregnancy rates appeared slightly lower in patients with intramural fibroids. However, patients with intramural fibroids also experienced more miscarriages [29] . Besides, occasionally submucosal fibroids may cause tubal obstruction; more commonly unilateral $[29,30]$.

\section{Medical and surgical history associated with tubal infertility}

In this study history of surgery for ectopic pregnancy and appendectomy has been associated with tubal 
infertility. However, infections that damage the tubes to cause ectopic gestation usually affect both tubes. In addition, surgery for ectopic pregnancy may lead to post-operative adhesions especially when done by open surgery or laparotomy [27, 31, 32]. That still, medical treatment of ectopic pregnancy with methotrexate has been reported in some studies in Cameroon and elsewhere [33-35]. This may lead to peritoneal adhesions that may impair fertility. Appendicitis may also lead to right tubal damage by contiguity thereby predisposing patients to pelvic peritonitis or ectopic pregnancy. However, several studies have reported that appendicitis is significantly associated to ectopic pregnancy and not to infertility [36-38]. However, a more recent study reported although previous appendectomy was associated with intra-abdominal adhesions, and these were in turn associated with tubal pathology, appendectomy was not directly associated with compromised tubal patency, but previous appendectomy may indirectly affect female fertility through mechanisms other than direct tubal obstruction [39].

Chronic pelvic pain was 7.3 times associated with tubal infertility. This is usually a corollary of organic damage to the genital tract and most often occurring after recurrent pelvic infections, chronic PID, pelvic surgery because of postoperative adhesions or endometriosis [40]. Endometriosis has been a silent cause of infertility in Cameroon because of peritoneal irritation, scarring and adhesion formation until the advent of laparoscopic surgery that brought clarity in its diagnosis.

In this study we found that diabetes mellitus has a 10.5 -fold association with tubal infertility. Besides, one study reported that a history of infertility, particularly that related to ovulation disorders and tubal blockage, is significantly associated with a higher risk of type-2 diabetes mellitus [41].

Other factors like early coitarche $(\mathrm{AOR}=2.93, p=$ 0.14 ), use of traditional herbs vaginally ( $\mathrm{AOR}=3.30, p=$ $0.23)$, multiple sexual partners $(\mathrm{AOR}=2.40, p=0.19)$ were not significant in the multivariate analysis. However, studies in Karachi-Pakistan have reported their roles in the genesis of tubal infertility [42].

\section{Prevention of tubal factor infertility}

The practice of safe sex has been advocated as a means of reducing sexually transmitted infections (STI's) and their sequelae that may lead to tubal infertility [43-45]. As already mentioned screening young girls for Chlamydia trachomatis and treating suspected cases of $C$. trachomatis infection is another important modality to avoid complications like pelvic inflammatory disease [27]. Furthermore, treatment of sexual partners of those infected will reduce reinfection among couples. However, caregivers who practice induced abortions should provide services to avoid post-abortal infections [46]. Finally, it is advisable to screen for Chlamydia trachomatis infection or administer prophylaxis against Chlamydia infection before invasive procedures like hysterosalpingography or hysteroscopy etcetera [47-49].

\section{Limitations and strengths of the study}

In this study, we used the Chlamydia antibody test (serology) to test for chlamydia because it is less expensive although it is less specific in establishing an association with infertility. The presence of chlamydia antibodies does not confirm that chlamydia is the cause of the tubal pathology that led to infertility. However, the casecontrol design of this study reduced bias and the interpretative power of the risk factors of tubal infertility. Furthermore, the results of this study were based on information obtained from patient's interviews, which could theoretically increase the risk of interviewer or responder bias as well as recall bias. Furthermore, we could not find out the compliance to treatment of these patients and their sexual practices during treatment for Chlamydia trachomatis infection that could lead to reinfection and chronicity. These may confound the outcome of treatment in favour of tubal damage and thereby accounting for the increase in tubal infertility reported in this study.

The use of in-depth patient interviews after a detailed explanation of study protocols limited recall bias. Additionally, infertile women and pregnant controls were motivated to report about earlier genital infections and other sexual problems that were requested from them because they believed that the researchers would educate them on their condition since these were sensitive issues. Besides, there is no significant difference between the two groups with regard to those under the age of 35, level of education, region of origin, and most professions aside from self-employed. This homogeneity of study population has made us to believe that the results of this study are valid and make an important contribution to risk factors of tubal infertility in Cameroon.

\section{Conclusion}

The following factors were independently associated with tubal infertility: being a housewife, self-employed, history of Chlamydia trachomatis and Mycoplasma infection, and uterine fibroids. Furthermore, a history of pelvic surgery and other surgeries, diabetes mellitus, and chronic pelvic pain were also associated with tubal infertility. Young age, those in monogamous marriages, and users of barrier methods of contraception (condom) were less likely to have tubal infertility. Identification of these factors is a target of intervention to avoid tubal infertility. 


\section{Abbreviations}

AOR: Adjusted odd ratio; C: Chlamydia; Cl: Confidence interval; DRH: Douala Referral Hospital; HSG: Hysterosalpingography; PID: Pelvic Inflammatory Disease; SPSS: Statistical Package for the Social Sciences; STI: Sexually transmitted infection

\section{Acknowledgements}

We are grateful to the study participants for the information they gave us in the realization of this study.

\section{Authors' contributions}

TOE, TNN, GPN and FE: Project development and Manuscript writing/editing. GPN, RT, AGS, CTN: Project development, Data collection or management and manuscript writing. TOE, CNNC, and GEHE: Data analysis and manuscript writing/editing. ME: Imaging studies and manuscript editing. All the authors approved the final manuscript.

\section{Funding}

None.

\section{Availability of data and materials}

The data supporting the conclusions in this article is included in the article.

\section{Ethics approval and consent to participate}

Administrative approval was obtained from the Managing Director of the Douala Referral Hospital (No 060 AR/MINSANTE/HGD/DM/02/17) while ethical clearance was obtained from the ethical board of "Université des Montaigne" Banganté (No 2017/006/Udm/PR/CIE).

Written informed consent was obtained from all individual participants included in the study.

\section{Consent for publication}

Not applicable.

\section{Competing interests}

The authors declare that they have no competing interests.

\section{Author details}

'Department of Obstetrics and Gynecology, Douala Referral Hospital, Douala, Cameroon. ${ }^{2}$ Faculty of Health Sciences, University of Buea, Buea, Cameroon. ${ }^{3}$ Faculty of Health Sciences, Université des Montagnes, Bangangte, Cameroon. ${ }^{4}$ Department of Radiology, Douala Referral Hospital, Douala, Cameroon. ${ }^{5}$ Faculty of Medicine and Pharmaceutical Sciences, University of Douala, Douala, Cameroon.

Received: 16 September 2019 Accepted: 21 February 2020

\subsection{0}

\section{References}

1. Brugo-Olmedo S, Chillik C, Kopelman S. Definition and causes of infertility. Reprod BioMed Online. 2001;2:173-85.

2. Uadia PO, Emokpae AM. Male infertility in Nigeria: a neglected reproductive health issue requiring attention. J Basic Clin Reprod Sci. 2015;4:45-53.

3. Gerrits T, Shaw M. Biomedical infertility care in sub-Saharan Africa: a social science review of current practices, experiences and view points. Facts Views Vis Obgyn. 2010;2:194-207.

4. Okonofua F. Infertility and Women's reproductive health in Africa/Infertilite et Santé reproductive des femmes en Afrique. Afr J Reprod Health Rev Afr Santé Reprod. 1999:3:7-12.

5. Mascarenhas MN, Flaxman SR, Boerma T, Vanderpoel S, Stevens GA. National, regional, and global trends in infertility prevalence since 1990: a systematic analysis of 277 health surveys. PLoS Med. 2012;9:e1001356.

6. Gerrits T. Biomedical infertility care in low resource countries: barriers and access. Facts Views Vis Obgyn Monog. 2012;2:1-6.

7. White L, McQuillan J, Greil AL. Explaining disparities in treatment seeking: the case of infertility. Fertil Steril. 2006:85:853-7.

8. Dyer SJ. Infertility-related reproductive health knowledge and help-seeking behaviour in African countries. ESHRE Monogr. 2008;2008:29-33.

9. Nana PN, Wandji JC, Fomulu JN, Mbu RE, Leke RJI, Woubinwou MJ. Aspects Psycho-Sociaux chez Patients Infertiles à laMaternite Principale de l'Hopital Central de Yaoundé, Cameroun. Clin Mother Child Health. 2011;8:1-5.
10. Catanzariti F, Cantoro U, Lacetera V, Muzzonigro G, Polito M. Comparison between WHO (World Health Organization) 2010 and WHO 1999 parameters for semen analysis-interpretation of 529 consecutive samples. Arch Ital Urol Androl. 2013:85:125-9.

11. Chalazonitis A, Tzovara I, Laspas F, Porfyridis P, Ptohis N, Tsimitselis G. Hysterosalpingography: technique and applications. Curr Probl Diagn Radiol. 2009;38:199-205.

12. Blaisdell MW. Method and apparatus for performing hysterosalpingography; 2000

13. Simpson WL Jr, Beitia LG, Mester J. Hysterosalpingography: a reemerging study. Radiographics. 2006;26:419-31.

14. Randolph ME, Pinkerton SD, Bogart LM, Cecil H, Abramson PR. Sexual pleasure and condom use. Arch Sex Behav. 2007:36:844-8.

15. Ramos RR, Gutiérrez GR, Monroy IA, Sánchez HGM. Risk factors associated to female infertility. Ginecol Obstet Mex. 2008;76:717-21.

16. Kelly-Weeder $\mathrm{S}, \mathrm{Cox} \mathrm{CL}$. The impact of lifestyle risk factors on female infertility. Women Health. 2007:44:1-23.

17. Ige OT, Ige SO, Olayinka AT. Prevalence of chlamydia trachomatis infection among women of reproductive age group in a tertiary hospital in northern Nigeria. Ann Trop Pathol. 2018;9:17.

18. Mensch BS, Grant MJ, Blanc AK. The changing context of sexual initiation in sub-Saharan Africa. Popul Dev Rev. 2006;32:699-727.

19. Gurtcheff SE, Klein NA. Diminished ovarian reserve and infertility. Clin Obstet Gynecol. 2011;54:666-74

20. Abshier CA, Kennard EA, Sroga JM. Predisposing risk factors may aid in identifying individuals with diminished ovarian reserve [176]. Obstet Gynecol. 2015;125:59S.

21. Maheshwari A, Hamilton M, Bhattacharya S. Effect of female age on the diagnostic categories of infertility. Hum Reprod. 2008;23:538-42.

22. Pellati D, Mylonakis I, Bertoloni G, Fiore C, Andrisani A, Ambrosini G, et al. Genital tract infections and infertility. Eur J Obstet Gynecol Reprod Biol. 2008:140:3-11.

23. Nwankwo EO, Sadiq MN. Prevalence of chlamydia trachomatis infection among patients attending infertility and sexually transmitted diseases clinic (STD) in Kano, North Western Nigeria. Afr Health Sci. 2014;14:672-8.

24. Francis SC, Mthiyane TN, Baisley K, Mchunu SL, Ferguson JB, Smit T, et al. Prevalence of sexually transmitted infections among young people in South Africa: a nested survey in a health and demographic surveillance site. PLoS Med. 2018;15:e1002512. https://doi.org/10.1371/journal.pmed.1002512.

25. Van den Broek IVF, Land JA, van Bergen JEAM, Morré SA, van der Sande MAB. Chlamydia trachomatis antibody testing in vaginal mucosal material versus blood samples of women attending a fertility clinic and an STI clinic. Obstet Gynecol Int. 2014;2014:601932. https://doi.org/10.1155/2014/601932.

26. Menon S, Timms P, Allan JA, Alexander K, Rombauts L, Horner P, et al. Human and pathogen factors associated with chlamydia trachomatisrelated infertility in women. Clin Microbiol Rev. 2015;28:969-85.

27. Hoenderboom BM, van Benthem BHB, van Bergen JEAM, DukersMuijrers NHTM, Götz HM, Hoebe CJPA, et al. Relation between chlamydia trachomatis infection and pelvic inflammatory disease, ectopic pregnancy and tubal factor infertility in a Dutch cohort of women previously tested for chlamydia in a chlamydia screening trial. Sex Transm Infect. 2019;95:300-6.

28. Shepard MK, Jones RB. Recovery of chlamydia trachomatis from endometrial and fallopian tube biopsies in women with infertility of tubal origin. Fertil Steril. 1989:52:232-8.

29. Brady PC, Stanic AK, Styer AK. Uterine fibroids and subfertility: an update on the role of myomectomy. Curr Opin Obstet Gynecol. 2013;25:255-9.

30. Sue W, Sarah S-B. Radiological appearances of uterine fibroids. Indian J Radiol Imaging. 2009;19:222.

31. Hajenius PJ, Mol F, Mol BWJ, Bossuyt PMM, Ankum WM, Van der Veen F. Interventions for tubal ectopic pregnancy. Cochrane Database of Systematic Reviews. 2007;(1):CD000324. https://doi.org/10.1002/14651858.CD000324. pub2.

32. Marcus SF, Brinsden PR. Analysis of the incidence and risk factors associated with ectopic pregnancy following in-vitro fertilization and embryo transfer Hum Reprod. 1995:10:199-203.

33. Cecchino GN, Júnior EA, Júnior JE. Methotrexate for ectopic pregnancy: when and how. Arch Gynecol Obstet. 2014:290:417-23.

34. Juneau C, Bates GW. Reproductive outcomes after medical and surgical management of ectopic pregnancy. Clin Obstet Gynecol. 2012:55:455-60 
35. Tchatou AS, Tchounzou R, Mbuagbaw L, Mboudou ET. Successful medical treatment of a hepatic pregnancy: a case report. J Med Case Rep. 2017;11:70

36. Elraiyah T, Hashim Y, Elamin M, Erwin PJ, Zarroug AE. The effect of appendectomy in future tubal infertility and ectopic pregnancy: a systematic review and meta-analysis. J Surg Res. 2014;192:368-74.e1.

37. Urbach DR, Cohen MM. Is perforation of the appendix a risk factor for tubal infertility and ectopic pregnancy? An appraisal of the evidence. Can I Surg. 1999:42:101-8.

38. Urbach DR. Association of perforation of the appendix with female tubal infertility. Am J Epidemiol. 2001;153(6):566-71.

39. Margaux Becker V, Silver S, Seufert R, Muensterer OJ. The Association of Appendectomy, adhesions, tubal pathology, and female infertility. JSLS. 2019;23:e2018.00099. https://doi.org/10.4293/JSLS.2018.00099.

40. Ayorinde AA, Macfarlane GJ, Saraswat L, Bhattacharya S. Chronic pelvic pain in women: an epidemiological perspective. Women's Health. 2015;11:851-64.

41. Tobias DK, Gaskins AJ, Missmer SA, Hu FB, Manson JE, Buck Louis GM, et al. History of infertility and risk of type 2 diabetes mellitus: a prospective cohort study. Diabetologia. 2015;58:707-15.

42. Sami N, Ali TS, Wasim S, Saleem S. Risk factors for secondary infertility among women in Karachi, Pakistan. PLoS ONE. 2012;7 e35828. https://doi.org/10.1371/journal.pone.0035828.

43. Da Ros CT, da Silva Schmitt C. Global epidemiology of sexually transmitted diseases. Asian J Androl. 2008;10:110-4.

44. Brunham RC, Gottlieb SL, Paavonen J. Pelvic inflammatory disease. N Engl J Med. 2015;372:2039-48.

45. Brady PC. Pelvic inflammatory disease and Tubo-ovarian abscesses. In: Handbook of consult and inpatient gynecology. Berlin: Springer; 2016. p. $121-33$.

46. Kim Y-S. Medical concerns of induced abortion and contraception. J Korean Med Sci. 2019;34:e137.

47. Egbe TO, Kobenge FM, Arlette MMJ, Belley-Priso E. Pyosalpinges after hysterosalpingography in a patient with lower genital tract infection and managed by laparoscopic surgery in a resource low tertiary hospital case report and literature review. Fertil Res Pract. 2018;4:2.

48. Darwish AM. Unexplained female infertility alert over overt and hidden genital infections. Genit Infect Infertil. 2016;21. http://dx.doi.org/10.5772/64 056.

49. Pereira N, Hutchinson AP, Lekovich JP, Hobeika E, Elias RT. Antibiotic prophylaxis for gynecologic procedures prior to and during the utilization of assisted reproductive technologies: a systematic review. J Pathog. 2016; 2016:4698314.

\section{Publisher's Note}

Springer Nature remains neutral with regard to jurisdictional claims in published maps and institutional affiliations.

Ready to submit your research? Choose BMC and benefit from:

- fast, convenient online submission

- thorough peer review by experienced researchers in your field

- rapid publication on acceptance

- support for research data, including large and complex data types

- gold Open Access which fosters wider collaboration and increased citations

- maximum visibility for your research: over $100 \mathrm{M}$ website views per year

At $\mathrm{BMC}$, research is always in progress.

Learn more biomedcentral.com/submissions 